\title{
CURRICULUM DESIGN FOR DISTANCE EDUCATION IN THE TERTIARY SECTOR
}

\author{
Ritesh CHUGH \\ School of Engineering \& Technology \\ CQUniversity, Melbourne, Australia \\ Shirley LEDGER \\ School of Nursing, Midwifery and Social Sciences \\ CQUniversity, Brisbane, Australia \\ Rebecca SHIELDS \\ School of Access Education \\ CQUniversity, Rockhampton, Australia
}

\begin{abstract}
A growing number of students globally are enrolling in distance education programs and it is becoming important now, more than ever before, to design curriculum that reflects educational principles, represents elements of engagement and pedagogy and meets institutional and industry requirements. In doing so, it is vital to design contemporary curriculum that ensures these outcomes are attained. This paper adopts a narrative and integrative approach to advance the understanding of curriculum design practices, with particular relevance to distance education. In order to effectively design curriculum, this paper views the role of the educator as a conductor, technician and choreographer. Finally, a triad has been proposed comprising of pedagogy, technology and an engaged community of learners as a basis for ensuring curriculum meets contemporary practices.
\end{abstract}

Keywords: Distance education, curriculum, curriculum design, online learning, tertiary.

\section{INTRODUCTION}

Higher education is an important part of educational systems worldwide. Enrolments in the tertiary sector globally reached 170 million, indicating a growth of $160 \%$ since 1990 (Sharma, 2012). In Australia, 1.3 million domestic and international students enrolled at higher education institutions in 2013 demonstrating an increase of 4.5 per cent over 2012 (Australian Government, 2014). In 2011, the gross enrolment ratio in the Australian tertiary education sector was one of the highest in the world (Organization for Economic Co-operation and Development, 2012).

A growing trend amongst students these days is to enroll in multi-modal programs i.e. delivered on-campus and through distance education. In $2010,7 \%$ of higher education students in Australia were studying in multi-modal programs (Australian Bureau of Statistics, 2012). Thirty-two percent of higher education students in America enrolled in at least one course online (Allen \& Seaman, 2013).

As a large number of students are taking courses online through technologically mediated distance education, it becomes important to understand their needs and design curriculum that reflects educational principles, represents elements of engagement and pedagogy and meets institutional and industry requirements. Simonson, Smaldino, Albright, and Zvacek (2009) have suggested that distance education courses should be carefully designed. Designing curriculum, especially one, that caters for traditional and distance education is a 
complex process (Passerini \& Granger, 2000). Effective curriculum design plays an important role in any educational system and is important in ensuring the learning journey of students is a successful one. Any changes to curriculum design must make it more responsive to market needs and should enable in achieving skills required by graduates in the 21st century. As distance education has become a vital alternative to face-to-face delivery, it is increasingly important curriculum design not only caters for the needs of faceto-face students but also for distance learners. Distance education provides various advantages in the form of flexibility for learners (Moore \& Kearsley, 1996), multiple online support mechanisms (Mohakud, Mohapatra \& Mandira, 2012), overcoming distance and time barriers (Berge, 2013) and making education accessible for everyone (Carr, 2012). There is contradiction about the use of the terms distance education and distance learning interchangeably (Moore, Dickson-Deane \& Galyen, 2010) with little clear consensus emerging; however, for the purposes of this paper these terms have been used interchangeably (Passerini \& Granger, 2000).

Whilst there have been reviews of literature (Zawacki-Richter, Bäcker \& Vogt, 2009; Anderson \& Dron, 2011) on distance education, yet these reviews have not specifically related curriculum design to higher education nor provided a focus on curriculum design for distance education in particular. It is crucial to overcome the shortage of writing on this subject (Hicks, 2007) hence, this paper attempts to plug in the gaps by providing a cohesive view. This integrative review paper lends transparency to the extant literature in curriculum design, and constitutes an important step in expanding and drawing upon past work, as well as more adequately provides a new birds-eye view of this landscape with combined insights and a comprehensive perspective.

This paper intends to be a useful source of information for curriculum developers and academic staff who need a general overview into rudiments of curriculum design. The paper's contribution is manifold as it endeavors to holistically provide an insight into key elements of curriculum design for distance learning in higher education. Firstly, this paper offers definitions of curriculum design and explores the distinction between curriculum design and instructional design, if any. Then, it explores the meaning of curriculum design specifically in the context of distance learning. Thirdly and very importantly, it provides an insight into practices that educators can adopt to design a contemporary curriculum for distance education that enhances learning and engagement. It also proposes a responsive approach to teaching in distance education environments that sees the educator as a conductor, technician and choreographer. It ends with a brief discussion of a proposed framework comprising of a triad of pedagogy, technology and an engaged community of learners to produce a contemporary curriculum design for distance education. Finally, in the conclusion section, the key points of the paper have been summarized and limitations are explicitly stated with avenues for future research.

\section{RESEARCH METHOD}

This review has undertaken a narrative and integrative approach by summarizing primary research and literature (Green, Johnson \& Adams, 2006; Whittemore \& Knafl, 2005). Integrative reviews accomplish an assortment of purposes such as defining concepts, reviewing evidence and theories and analyzing methodological issues of a topic (Broome, 1993), with an aim to comprehensively understand concepts, theories and specific phenomenon (Whittemore \& Knafl, 2005). The aim of such reviews is to present a qualitative blend of data (Polkinghorne, 1995). A narrative review is deemed to be important when linking together multiple studies for the purposes of reinterpretation or interconnection (Baumeister \& Leary, 1997). As such, this paper involves an interpretation of the extant literature in this field and then making propositions based on it. The following sections now offer our synthesis and interpretation of the curriculum design literature with particular relevance to distance education. 
Key Elements of Curriculum Design

When examining curriculum design, there are inconsistencies in definitions, as well as multiple ideas around what curriculum design is or how it should be done. Looking at the individual terms, curriculum and design, will help better define what curriculum design collectively is. The International Education Association of Australia (2013, p. 3) state that, 'Curriculum is defined in the widest sense to include everything that shapes the student's learning experience.' McKimm (2007) relates with this description, going further to highlight that curriculum is often misconstrued as syllabus whereas content is the syllabus. The University of Manchester (2014) claims curriculum is a planned sequence of learning experiences and assert that 'In designing a curriculum, whether for a whole degree program or for a particular unit, you are planning an intellectual 'journey' for your students - a series of experiences that will result in them learning what you intend them to learn' (p.1). Toombs \& Tierney (1993) highlight the vast differences of meanings of what curriculum is, from the narrow view of what is taught, to the broad view of everything that the student experiences. It is clear from the many different interpretations of what a curriculum is, that there is no absolute meaning or clear consensus, rather it is a fitness for purpose. For the purposes of this paper, curriculum refers to the overall learning experiences of the student, encompassing everything from the syllabus (content), right through to the general learning experiences of the student through interactions with the course content, instructors and other students.

When looking at curricula, there are intended curricula, and informal or hidden curricula (Kommalage, 2011). Intended curricula or a formal curriculum is what was organized or intended for the student to experience and go through, often externally accredited (outcomes, course content and assessment). The hidden curriculum are all the other nonintended but cultural experiences that the student would experience. So, although there can be design around the curriculum, as in, formal opportunities for the students to learn, there are also hidden or informal opportunities in curriculum that need to be considered in the design process (Kommalage, 2011).

What is design in relation to curriculum? The Oxford Dictionaries defines design as the 'purpose or planning that exists behind an action, fact, or object' (2014, p. 1 of 1). Toombes \& Tierney (1993) take the idea of purpose or planning further by highlighting that '... design defines a problem and formulates a solution' (p. 181). Herrick (1950) cited in Short (1986) observes the function of design was to '... help select and organize learning experiences and to indicate the role of teachers and pupils in curriculum planning and development' ( $p$. 3). The University of Manchester (2014) delves deeper into this explanation of curriculum design addressing the idea that, 'Curriculum design includes consideration of aims, intended learning outcomes, syllabus, learning and teaching methods, and assessment' (p.1). When considering all the meanings behind the two words, curriculum and design; curriculum design could then be described as a structure in which planning, problem and solution finding occurs and leads to the aims, intended learning outcomes, syllabus, learning and teaching methods and assessment, as well as other non-intended learning experiences of the learner.

An ongoing discussion is the distinction between curriculum design and instructional design. Petrina (2007) argues there is no distinction, that curriculum design and instructional design are one and the same while Kanuka (2006) argues that the two have similar purposes but are quite different in their approach. The distinction between the two terms is that curriculum design focuses on "what" the learner will learn as opposed to the instructional design focusing on "how" they will learn it. Kanuka (2006) defines instructional design as 'the process of translating general principles of learning and instruction into plans for instructional materials and learning activities' (p. 3). When comparing this meaning of instructional design to the constructed meaning of curriculum 
design, the two appear to have a large overlap. Hence, for the purposes of this paper, the two terms have been used interchangeably.

What Does Curriculum Design Mean for Distance Learning?

There is an ever increasing trend of students deciding to take up study via distance (Australian Bureau of Statistics, 2012; Allen \& Seaman, 2013). For whatever reasons students may have behind choosing this type of study, the design approach to distance education needs to be carefully planned and thought out (Simonson et al. 2009). Designing curriculum and learning for distance education is different to designing learning for internal or face to face students. The needs of the learner in a distance education course or program are vastly different to the needs of learners choosing other modes of study. When designing any learning, the learner and their needs should be at the forefront of the design process (Smaldino \& Simonson, 1999). Coupled with this, should be a sound understanding of the medium through which the instruction or learning experience occurs. Smaldino \& Simonson (1999) place emphasis on a few elements that should be remembered when designing learning for distance education - 'the content, the learner, the strategies for teaching, and the means for assessing the learning experience' (p. 215). Failure to consider all of these elements when designing and planning learning for distance can mean that the intended learning experiences of the learners may not be achieved.

In order to understand what factors come into the forefront when designing curriculum for distance learning, first, the meaning of distance education or learning has been identified. Moore \& Kearsley $(1996$, p.2) identify distance education as:

...planned learning that normally occurs in a different place from teaching and as a result requires special techniques of course design, special instructional techniques, special methods of communication by electronic and other technology, as well as organizational and administrative arrangements.

It is vital to note that Moore \& Kearsley (1996) highlight that different techniques of course design, instruction and communication are required for distance education. Smaldino and Simonson (1999) agree with this notion, arguing that when planning for teaching at a distance the course materials that were used for internal classes cannot just be reproduced for the online environment. Special consideration needs to be given to how the course content is going to be relayed to students who may access and interact with course materials in a synchronous or asynchronous manner, as there are different dynamics online than teaching face to face. As well as this, other media, visuals or more dynamic and interactive technology needs to be used in distance courses, to encourage interactivity. The effectiveness of learning and teaching technologies will always be challenging due to subjectiveness and imprecision of human decision making (Wibowo, Grandhi, \& Chugh, 2014). Another facet to teaching at a distance is that there need to be activities that encourage interactivity, and students may have to be shown how to do this (Durrington, Berryhill \& Swafford, 2006). In face to face classes, the use of visual cues helps the instructor to adjust teaching or materials. This is not feasible at a distance and other methods such as regular monitoring of online discussion forums need to be undertaken (Smaldino \& Simonson, 1999). Lastly, technical issues are one of the biggest complaints of students who study and learn at a distance. There needs to be integration of training or information in the use of the technology that is to be used for the students as well as the staff. Technical issues need to be accounted for in the design (Moller, Foshay \& Huett, 2008).

Good curriculum design, for distance education is imperative for success. Educators, instructors and curriculum developers need to take into account the differences between constructing courses or programs that work in a distance or online world and ones that work face to face. Without these considerations, the intended or mapped learning journey 
of the student may not be reached. The next section now focusses on practices educators can adapt to design a contemporary curriculum for distance education.

\section{Practices to Design a Contemporary Curriculum for Distance Education}

Distance education is heavily shaped and constructed by the technology that assists and supports different models of learning, connecting and engaging. Technology assists by making learning accessible and portable. The classroom is wherever and whenever the student and educator choose as appropriate to their needs and lifestyle. In fact, the term 'distance education' could be considered a somewhat outdated construct, and equally as a paradox; that is 'distance' education, borne prior to the digital era (Santally, Rajabalee and Cooshna-Naik, 2012). With the post-industrial approach of 'on-line' learning having gained wide use and acceptability, the narrative for educators is thick with terms including student centered, transformative, systemic and collaborative learning spaces.

According to the 2014 NMC Technology Outlook on Australian Tertiary Education report, the 145 acknowledged experts in this area 'strongly agree that mobile learning and online learning, in some form, will likely tip into mainstream use within the next year - a trend that spans education across much of the world' (Johnson, Becker, Cummins, \& Estrada, 2014, p.2). As a globally connected society, networked through many online environments, the focus is on the 'social' aspects of learning; that is 'learning with and from others by moving within one's culture, workplace and world' (Bozarth, 2012, p.66). This provides an abundance of opportunity for educators to embrace alternative methods of teaching and learning practices from each other and from the community of learners with whom we engage. Given this dynamic learning environment how can educator's design curriculum that plans for both the intellectual, technological and social journey for students whilst also mapping and ensuring the attainment of the learning outcomes intended?

In our attempt to answer this question, the creative interface between pedagogy and technology can be viewed somewhat theatrically, as 'the technology sets the beat and creates the music, while the pedagogy defines the moves' (Anderson \& Dron, 2011, p. 81). In terms of teaching and design practices in this era, the 'moves' are likely to be the product of collaborative invention from the student experience and this section of the paper will propose a responsive approach to teaching and design of curriculum in distance education environments.

Drawing from this metaphor, the academic or educator must be all of these things in distance education; conductor, technician and choreographer. The conductor role (teaching and facilitation) in online or distance education contemporary curriculum development sits comfortably within an ecosystems perspective where an engaged and critically reflective community of learners are immersed in an environment where the technology supports and enables relationships of learning to flourish (Tucker, 2014). The technician role therefore encompasses the teaching dimensions and techniques utilized for effective learning, in combination with the learning management systems and tools and as such must be supported by an institutional structure that enables access and equity to the learning environment. The choreographer's role focusses on the educator being involved in the design of learning activities, which also includes regular improvisation of curriculum in order to stay innovative. The choreographer aka educator also ensures their tacit knowledge is transferred to students through 'show and tell' and practice activities. The educator in the choreographer's role is vital in the pedagogical positioning of the curriculum in distance education as it varies from instructivist information delivery approaches to constructivist relational and student led environments (Herie, 2005; Hiltz \& Turoff, 2005). Student engagement remains a central driver for educators irrespective of pedagogy particularly in terms of the global integration of new technologies to higher education settings. Flipped classrooms, microcredits and social learning are just some of these emerging technology based approaches to teaching and learning. The Bring Your Own 
Device (BYOD) movement in Australian universities has been developed, connecting student's mobiles or laptops and tablets to the corporate network for engaged learning.

The structure and design of curriculum, in this context, needs to intentionally and purposefully provide the opportunities for experimentation and new learning with carefully supported environments providing clear expectations of students and the educator at the beginning and throughout the course. Creative activities need to lead to learning the desired concepts and instructions around expectations of pace (self or group). In order to design the type of learning content that will encourage interaction and collaboration, the educator needs to consider both synchronous and asynchronous styles (Chugh, 2010). Providing clear instruction around whether activities are synchronous or asynchronous; sequential or clarified (Van Duzer 2002) is also recognized as important for effective curriculum design in distance education. This is largely due to the techniques utilized to engage and sustain the community of students shifting significantly from the traditional cognitive-behavioral model of distance education where educators attempted to 'transmit' knowledge and their personality through writing style alone (Anderson \& Dron, 2011) to more synchronous interaction, the use of social media tools such as blogs, vodcasts, podcasts and virtual classroom spaces. However, asynchronous formats also allow for depth of processing and reflection as students are able to take more time to consider their responses (Wise, Perera, Hsiao, Speer, \& Marbouti, 2012). Learner or student led activities can be successful in both asynchronous and synchronous learning environments although it seems that a greater degree of success occurs when a combination of different forms of synchronous and asynchronous online interactions, as well as face to face interactions are utilized, despite there being little evidence that one is superior to the other in terms of learning (Johnson, 2008). In this way, curriculum design practices should also consider student cognitive styles and learner expectations.

Curriculum design that solicits deeper reflection and engagement from students rests on the sociocultural learning theories such as constructivist learning approaches generating higher levels of student responsibility for learning, assisting them to be better prepared and display a heightened student agency (Wilson, 2001). With this and student engagement strategies in mind, student involvement in the design of discussion topics, assessment criteria, critique of major works, case studies and so forth may provide opportunities for higher order thinking skills to be demonstrated and counteract potential superficial learning. These practices acknowledge the risks that students may be rarely engaged in the knowledge negotiation, refinement or construction phases and therefore guidance or structures for participation should be targeted towards depth of processing. The promotion of interaction and communication needs to be similarly embedded into distance education curriculum through icebreakers, introductions, the educator modelling interaction approaches and providing prompts to those that are not engaging and importantly, provision of information about netiquette. Elements of authentic learning were applied in one study where higher education practitioners experienced online learning from a student perspective following authentic learning guidelines (Parker, Maor \& Herrington, 2013). The use of reality projects, case studies, problem solving and simulated learning opportunities were supported within a protected environment of support, monitoring, discussion boards, feedback and critical reflection opportunities. The study indicated the higher order thinking skills such as critical thinking and problem solving were fostered in this course utilizing authentic learning principles.

A meta-analysis of experimental and quasi-experimental studies around online practices conducted by the United States Department of Education (2010) highlighted examples of regularly utilized activities, their influence on learning effectiveness and how they could form an important part of curriculum. This study indicated, for example video and online quizzes having limited influence in the amount or enhancement of learning for students and supported its use as an assessment tool only. While the technology allows for interactivity, this in itself is not particularly engaging or focused on the learning process. The study supported student led interaction with the media available online as enhancing 
learning, while opportunities to trigger reflection and intrinsic motivation were particularly effective. Guidance or discussion with students would normally be managed by the educator in real time in a face-to-face environment (Brown \& Voltz, 2005). In an online environment, the unpredictability of the student context and the mediated relationship with the student requires careful attention to details which might otherwise be managed by the educator at the time of instruction in a face-to-face environment. This aspect of feedback or guidance provided to students as part of their distance education learning experience is also critically important and therefore needs to be planned and designed. There are a range of feedback strategies that can be utilized to establish action-orientated dialogue with students from the individually based responses such as email, personal messages, to comments on group forums, to reflective responses to questions, stimuli or forums (Brown \& Voltz, 2005). The notion of learning relationships is evident in contemporary engagement practices in distance education and online environments. Haley and Parise (2014) point out the value of the 'capital' derived from such practices in their study on the pedagogical capital associated with the human dynamics involved in the instructor-student relationship, as having significant value for student engagement.

Importantly, it may be that the community and relational aspect of teaching and learning synthesizes to produce a contemporary curriculum design for distance education in the form of a triad (as illustrated in figure 1) comprising pedagogy, technology and an engaged community of learners. In continuation of the theatrical metaphor; the fusion of pedagogy, technology and community of learners combine to create a symphony of learning. The facilitation of all three requires not only technical expertise in curriculum design practices, but an understanding and purposeful design approach to the socio-cultural elements of the community, including the netiquette required to communicate in online spaces and in roles that may emerge differently than in classroom-based education.

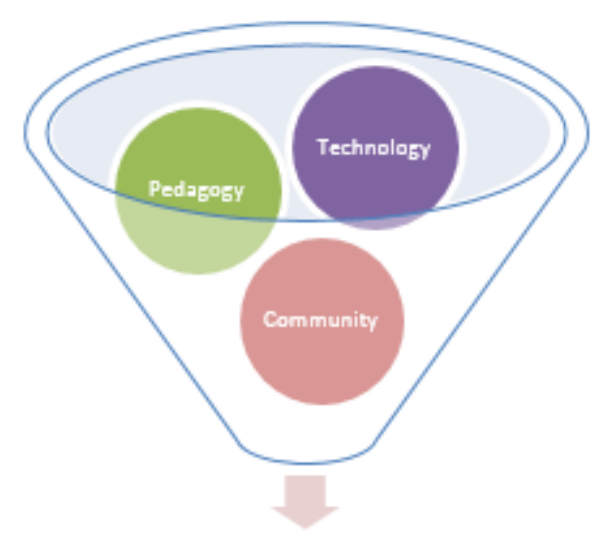

Curriculum Design

Figure 1. Triad for contemporary curriculum design

Educators may need to consider practices that not only support these elements in learning but identify and acknowledge their presence transparently. Educators are likely to be reflecting on and revising their own previously utilized didactic interaction style in light of this triad, engaging with students in a more personable and informal manner while also recognizing that this process will need to be repeated with each new community of learners. This aspect in itself may need to be considered a particularly important educational practice requiring further research; that is how does the educator facilitate and understand the forming, norming, storming, performing and adjourning phases (Tuckman \& Jensen, 1977) in an online or distance education environment at the mezzo level while also understanding the cultural aspects of the macro online community of learners. The alignment of learner needs with pedagogy, technology and an engaged community of learners appears to provide the beginnings of a coherent framework for engaged learning to flourish. 


\section{CONCLUSION}

This paper has reviewed the extant literature on curriculum design with a specific focus on distance education with the aim of proving a holistic view of this discipline. A common thread running through all the practices presented in this paper are about ensuring learning outcomes are delivered and contemporary educational practices are adopted in curriculum design. This paper has furthered understanding of curriculum design practices, with particular relevance to distance education.

We have provided a holistic definition of curriculum design with a specific focus on distance education. The paper will be a useful source of practices that educators can adapt to kickstart and/or improve curriculum design for distance education. In order to design a contemporary curriculum for distance education and for learning to be successful, we have argued that it is vital to incorporate a mixture of synchronous and asynchronous environments. Very importantly, we have proposed that the educator must be the conductor, technician and choreographer in the provision of distance education. The proposed triad comprising of pedagogy, technology and an engaged community of learners can be used as a basis for ensuring curriculum meets contemporary practices.

A knowledge of specific contexts and needs should be established before designing curriculum. The paper has not specifically focused on any particular discipline however it is unequivocal that there will be elements of curriculum design that will need to be tailored to meet discipline specific requirements. Nevertheless, it is also evident through the definitions of curriculum design that curricula should identify competencies that students will achieve and the content that will be delivered. Given the expansion of the distance education market, realistically it may not be possible to design curriculum to serve only one cohort of students, hence curriculum design should accommodate and serve the needs of both distance learners and learners in the traditional classroom environment. The proposed triad has not been tested and follow-up work can focus on examining it to see how it more closely meets the needs of curriculum designers. Hence, it is open to revision, refinement and reformulation.

Inevitably, there is compelling logic in adapting curriculum design practices that focus on learning, connecting and engaging. Carefully designed curriculum will go a long way in supporting the needs of distance education learners, demands of the workplace and educators alike.

\section{BIODATA and CONTACT ADDRESSES of AUTHORS}

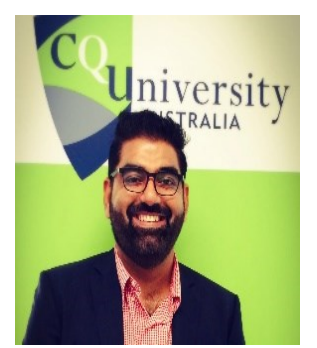

Ritesh CHUGH is a senior lecturer in the School of Engineering and Technology, CQUniversity. He teaches to both undergraduate and graduate students in the fields of Information Systems (IS) Management, Process Analysis and Design, and IS Project Management. Ritesh is an enthusiastic and committed educationalist who has been awarded several academic and teaching awards to recognise his teaching excellence, commitment to improved student outcomes and engagement in reflective learning and teaching activities.

Ritesh is also an active researcher and has published numerous articles in international refereed journals and contributed to several book chapters. He has presented and published papers in many peer reviewed international conferences too. His range of multidisciplinary research interests include social media, knowledge management, tacit knowledge ubiquity, information systems management, project management, electronic commerce and developing varied teaching and learning practices on a formal note and philately and numismatics on a more casual note. 


\section{Ritesh CHUGH}

School of Engineering \& Technology, Tertiary Education Division

Address: CQUniversity Melbourne, 120 Spencer St, Melbourne VIC 3000, Australia

Phone: +61 396160535

E-mail: r.chugh@cqu.edu.au

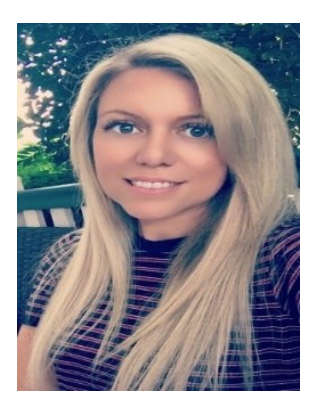

Shirley LEDGER is a lecturer in the Bachelor of Social Work program at CQUniversity where she has been a faculty member since 2011. Shirley was Discipline Lead for the program in $\mathbf{2 0 1 6}$ and co-coordinated the field education program for the discipline since 2013. She teaches child and family professional practice, field education and social work theory courses to students from across Australia undertaking a distance education mode of the professional degree.

Shirley is completing her PhD in the area of signature pedagogies for Australian social work education and her research interests lie in the area of social work field education, scholarship of teaching and learning and social work education. Shirley's social work career has included working in child protection, domestic and family violence, young women's health, inter country adoption and in private practice as an expert witness to Courts in child protection and family court matters.

\section{Shirley LEDGER}

Social Work, School of Nursing, Midwifery and Social Sciences

Address: CQUniversity Brisbane, 160 Ann St, Brisbane QLD 4000, Australia

Phone: +61 0408850694

E-mail: s.ledger@cqu.edu.au

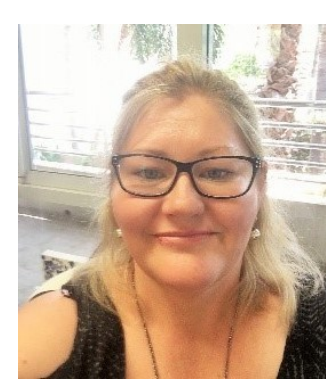

Rebecca SHIELDS is an Associate Lecturer in the School of Access Education, Tertiary Education Division, CQUniversity. Rebecca gained her Master of Education in October, 2015, where she focused on online learning, learning futures and special education. Her academic interest areas are open and distance learning, education futures, e-learning, special education and the use of technology in teaching students with disabilities. She has published and presented academic papers. Her teaching experience spans three countries, having taught in the UK, Japan and Australia, in primary school settings, high school settings and in higher education.

\section{Rebecca SHIELDS}

School of Access Education, Tertiary Education Division

Address: CQUniversity Rockhampton, QLD 4701 Australia

Phone: +61 0749232173,

E-mail: r.shields@cqu.edu.au

\section{REFERENCES}

Allen, I.E. \& Seaman, J. (2013). Changing course: ten years of tracking online education in the United States, Babson Survey Research Group and Quahog Research Group, Babson Park, MA. Retrieved 10 February 2016 from http://www.onlinelearningsurvey.com/reports/changingcourse.pdf

Anderson, T. \& Dron, J. (2011). Three generations of distance education pedagogy. International Review of Research in Open and Distance Learning, 12 (3), 80-97. 
Australian Bureau of Statistics. (2012). Education and training: higher education, 1301.0 Year Book Australia. Retrieved 10 February 2016 from http://www.abs.gov.au/ausstats/abs@.nsf/Lookup/by\%20Subject/1301.0 201 2 Main\%20Features Higher\%20education 107

Australian Government. (2014). Summary of the 2013 full year higher education student statistics. Department of Education. Retrieved 10 February 2016 from https://docs.education.gov.au/system/files/doc/other/2013studentsummary.pdf

Baumeister R.F. \& Leary M.R. (1997). Writing narrative literature reviews. Review of General Psychology, 1 (3), 311-320.

Berge, Z.L. (2013). Barriers to communication in distance education. Turkish Online Journal of Distance Education, 14 (1), 374-388.

Bozarth, J. (2012). From traditional instruction to instructional design 2.0. $T+D, 66$ (3), 64-67.

Broome M.E. (1993). Integrative literature reviews for the development of concepts. In B.L. Rodgers \& K.A. Knafl (Eds), Concept Development in Nursing, 2nd edn, Philadelphia: W.B. Saunders Co.

Brown, A. \& Voltz, B. (2005). Elements of effective e-learning design. The International Review of Research in Open and Distance Learning, 6 (1).

Carr, N. (2012). The crisis in higher education. MIT Technology Review. Retrieved 10 February 2016 from http://www.technologyreview.com/featuredstory/429376/ the-crisis-in-higher-education/

Chugh, R. (2010). E-learning tools and their impact on pedagogy. In Ubha, D.S. \& Kaur J. (eds), Emerging Paradigms in Commerce and Management Education, GSSDGS Khalsa College Press, Patiala, India, 58-81, ISBN: 978-81-909755-2-0. https: // www.researchgate.net/publication/275771731_E-learning_tools_and_ their_impact_on_pedagogy

Durrington, V., Berryhill, A. \& Swafford, J. (2006). Strategies for enhancing student interactivity in an online environment. College Teaching, 54 (1), 190-193.

Green B.N., Johnson C.D., \& Adams A. (2006). Writing narrative literature reviews for peer-reviewed journals: secrets of the trade. Journal of Chiropractic Medicine, 5 (3), 101-117.

Haley, G., \& Parise, P. (2014). Pedagogical capital and the relationship between social networking and quality of academic life in distance programs. Academy of Business Research Journal, 1, 27-43.

Herie, M. (2005). Theoretical perspectives in online pedagogy. Journal of Technology in Human Services, 23, 1/2, 29-52.

Herrick, V.E. (1950). Concept of curriculum design. In V.E. Herrick \& R.W. Tyler (Eds.), Toward improved curriculum theory (pp. 37 -50), Chicago: University of Chicago Press.

Hicks, O. (2007). Curriculum in higher education in Australia - Hello? In Enhancing Higher Education, Theory and Scholarship, Proceedings of the 30th HERDSA Annual Conference [CD-ROM], 8-11 July, Adelaide. 
Hiltz, S. \& Turoff, M. (2005). Education goes digital: the evolution of online learning and the revolution in higher education. Communications of the ACM, 48 (10), 59-64.

Johnson, G. (2008). The relative learning benefits of synchronous and asynchronous textbased discussion. British Journal of Educational Technology, 39 (1), pp. 166-169.

Johnson, L., Becker, S.A, Cummins, M., \& Estrada, V. (2014). 2014 NMC technology outlook for Australian tertiary education: a horizon project regional report. Austin, Texas: The New Media Consortium.

Kanuka, H. (2006). Instructional design and eLearning: A discussion of pedagogical content knowledge as a missing construct. e-Journal of Instructional Science and Technology, 9 (2), 1-17.

Kommalage, M. (2011). Hidden and informal curricula in medical schools: impact on the medical profession in Sri Lanka. Ceylon Medical Journal, 56 (1), 29-30.

McKimm, J. (2007). Curriculum design and development. Retrieved 12 February 2016 from http://www.faculty.londondeanery.ac.uk/e-learning/setting-learningobjectives/Curriculum_design_and_development.pdf

Mohakud, L.L., Mohapatra, R.L., \& Mandira, S. (2012). Encouraging higher education through open and distance learning (ODL): some aspects. Turkish Online Journal of Distance Education, 13 (4), 359-368.

Moller, L., Foshay, W.R., \& Huett, J. (2008). The evolution of distance education: implications for instructional design on the potential of the web. Tech Trends; Linking Research \& Practice to Improve Learning, 52 (4), 66-70.

Moore, J.L., Dickson-Deane, C., \& Galyen, K. (2010). e-Learning, online learning, and distance learning environments: are they the same? Internet and Higher Education, 14, 129135.

Moore, M. \& Kearsley, G. (1996). Distance education: a systems view, Chicago: Wadsworth Publishing.

Organisation for Economic Co-operation and Development. (2012). Education at a Glance 2012: OECD indicators. OECD Publishing. Retrieved 19 February 2016 from http://dx.doi.org/10.1787/eag-2012-en

Oxford Dictionaries. (2014). Design. Retrieved 19 February 2016 from http://www.oxforddictionaries.com/definition/english/design

International Education Association of Australia. (2013). Good practice principles in practice: Teaching across cultures. A quick guide to curriculum design. Retrieved 11 February 2016 from http://www.ieaa.org.au/documents/item/127

Parker, J., Maor, D., \& Herrington, J. (2013). Authentic online learning: aligning learner needs, pedagogy and technology. Issues in Educational Research, 23 (2), 227-241.

Passerini, K. \& Granger, M.J. (2000). A developmental model for distance learning using the Internet. Computers \& Education, 34, 1-15.

Petrina, S. (2007). Advanced teaching methods for the technology classroom, Hershey: Idea Group Inc.

Polkinghorne, D. (1995). Narrative configuration in qualitative analysis. Qualitative Studies in Education, 8 (1), 5-23. 
Santally, M., Rajabalee, Y., \& Cooshna-Naik, D. (2012). Learning design implementation for distance e-Learning: blending rapid e-Learning techniques with activity-based pedagogies to design and implement a socio-constructivist environment. European Journal of Open, Distance and E-Learning, pp.1-14.

Sharma, Y. (2012). Fast pace of higher education enrolment growth predicted to slow, University World News. Retrieved 10 February 2016 from http://www.universityworldnews.com/article.php?story=2012031308172724

Short, E.C. (1986). A historical look at curriculum design. Theory into Practice, 25 (1), 3-9.

Simonson, M., Smaldino, S., Albright, M., \& Zvacek, S. (2009). Teaching and learning at a distance: foundations of distance education (4th ed.). Upper Saddle River: Pearson. NJ.

Smaldino, S. \& Simonson, M. (1999). Instructional design for distance education. Paper presented at the National Convention of the Association for Educational Communications and Technology, Houston, TX, 215-219.

The University of Manchester. (2014). Teaching and Learning Support Office. Curriculum Design. Retrieved 10 February 2016 from http://www.tlso.manchester.ac.uk/ map/teachinglearningassessment/teaching/curriculumdesign/

Toombes, W.E. \& Tierney, W.G. (1993). Curriculum definitions and reference points. Journal of Curriculum and Supervision, 8 (3), 175-195.

Tuckman, B. \& Jensen, M. (1977). Stages of Small-group development revisited. Group \& Organization Studies (pre-1986), 2 (4), 419-427.

Tucker, S. (2014). Transforming pedagogies: integrating 21st century skills and web 2.0 technology. Turkish Online Journal of Distance Education, 15 (1), 166-173.

United States Department of Education (2010). Evaluation of evidence-based practices in online learning: a meta-analysis and review of online learning studies. Office of Planning, Evaluation, and Policy Development, Washington, D.C.

Van Duzer, J. (2002). Instructional design tips for online learning. Humboldt State University. Retrieved 12 February 2016 from http://www.csuchico.edu/tlp/resources/rubric/ instructionalDesignTips.pdf

Whittemore, R. \& Knafl, K. (2005). The integrative review: updated methodology. Journal of Advanced Nursing, 52 (5), 546-553.

Wibowo, S., Grandhi, S., \& Chugh, R. (2014). Assessing the effectiveness of learning and teaching technologies for teaching distance mode students in higher education. In Proceedings of the 3rd IEEE Conference on e-Learning, e-Management and eServices, Melbourne, Australia, December 10-12, 24-29.

Wilson B.G. (2001). Sense of community as a valued otcome for electronic courses, cohorts, and programs. Paper presented at VisionQuest PT3 Conference, Denver. Retrieved 19 February 2016 from http://carbon.ucdenver.edu/ bwilson/SenseOfCommunity. html.

Wise, A.F., Perera, N., Hsiao, Y., Speer, J., \& Marbouti, F. (2012). Microanalytic case studies of individual participation patterns in an asynchronous online discussion in an undergraduate blended course. Internet and Higher Education, 15 (2), 108-117.

Zawacki-Richter, O., Bäcker, E., \& Vogt, S. (2009). 'Review of distance education research (2000 to 2008): analysis of research areas, methods, and authorship patterns. International Review of Research in Open \& Distance Learning, 10 (6), 21-50. 